Psychother. Psychosom. 1986;45:I-IV

\title{
Contents, Vol. 45, 1986
}

\section{Contents Vol. 45,1986}

No. 1 Dedication to John C. Nemiah, MD

Editor's Note

Sifneos, P.E 1

Introduction to the Afternoon Program for Dr. Nemiah

Fishman, G 2

Was Robert Whytt (1714-1766) Right? Remarks on the Retirement of John C. Nemiah as

Psychiatrist-in-Chief, Beth Israel Hospital

Weiner, $\mathrm{H} \quad 5$

Why the Future Belongs to Psychiatry

Havens, L.L 14

Terminality and Interminable Psychoanalysis: An Incomplete Report

Weisman, A 23

Remarks for the Banquet to Honor John Nemiah on His Retirement from the Chairmanship of Beth Israel's Psychiatric Service

Frankel, F.H 33

Original Paper

Influence of Partnership on the Outcome of Psychotherapy

Riehl, A

37

Anorexia nervosa in Monozygotic Twins

Suematsu, H.; Kuboki, T.; Ogata, E 46

Book Reviews $\quad 51$

Announcement 56

No. 2 Personality Traits That Can Affect Adaptation after Colectomy. Study of 10

PatientsTreated for Ulcerative Colitis either with Proctocolectomy and Ileostomy or with

Colectomy, Proctomucosectomy, Heal Pouch and Ileoanal AnastomosisWeinryb, R.; Rössel, R 57

Influence of Alexithymic Characteristics on Physiological and Subjective Stress Responsesin

Normal IndividualsMartin, J.B.; Pihl, R.0 66

Low-Back Pain: A Psychosomatic Clinical Study

Villard, H.-R; Imbeault, J,; Duguay, M 78

Psychological Meaning of Illness and Coping with Disease

Keltikangas-Järvinen, L 84

Cervicobrachial Neuralgia and Low-Back Pain: Psychological Problems

Curci, P.; Gozzi, M.; Mari, M 91

IV Contents

Depression in the Hospitalized Inpatient with Various Medical Illnesses

Cavanaugh, S. v. A '. 
Integrated Psychotherapeutic Treatment of Somatoform and Other

PsychophysiologicalDisordersMoss, E.; Garb, R 105

No. 3 Comparison of Depressed and Nondepressed Women with Severe Premenstrual Tension Syndrome

Siegel, J.P.; Meyers, B.; Dineen, M.K

An Oriental Point of View in Psychosomatic Medicine

Ikemi, Y.; Ikemi, A 118

Relation of Family Factor to Treatment Outcome for Bulimic Patients

Krener, P.G.; Abramowitz, S.I.; Walker, P.B 127

Prediction of Alexithymic Characteristics from Physiological, Personality, and Subjective

Measures

Martin, J.B.; Pihl, R.O.; Young, S.N.; Ervin, F.R.; Tourjman, S.V 133

Emotions and Personality in Complex Partial Seizures

Perini, G.I 141

Amenorrhea and Predictors for Remenorrhea in Anorexia nervosa: A Psychoendocrinological Study in Inpatients

Meyer, A.-E.; von Holtzapfel, B.; Deffner, G; Engel, K.; Klick, M 149

The Schalling-Sifneos Personality Scale Revised

Sifneos, P.E 161

Book Reviews $\quad 166$

Announcements $\quad 168$

No. 4 Alexithymia and Handedness. A Pilot Study

Rodenhauser, P.; Khamis, H.J.; Faryna, A 169

Psychoendocrinology of Remenorrhea in the Late Outcome of Anorexia nervosa

Meyer, A.-E.; von Holtzapfel, B.; Deffner, G.; Engel, K.; Klick, M 174

Significance of Allergy in Asthma from a Behavioral Medicine Viewpoint

Wistuba, F 186

Prevalence and Psychodynamic Intepretation of Premorbid Hyperactivity in Patients with

Chronic Pain

Van Houdenhove, B 195

Development of an Analog Alexithymia Scale. Testing in a Nonpatient Population

Faryna, A.; Rodenhauser, P.; Torem, M 201

Toronto Alexithymia Scale: Relationship with Personality and Psychopathology Measures

B. Bagby, R.M.; Taylor, G.J.; Ryan, D 207

Author Index 216 